\title{
Wildlife conservation in a fragmented landscape: the Eurasian red squirrel on the Isle of Wight
}

\author{
Emilie A. Hardouin ${ }^{1}$ (1) Helen Butler ${ }^{2} \cdot$ Marin Cvitanović ${ }^{1} \cdot$ Rainer G. Ulrich ${ }^{3,6} \cdot$ Vanessa Schulze $^{3}$. \\ Anna-Katarina Schilling ${ }^{4}$ Peter W. W. Lurz ${ }^{4} \cdot$ Anna Meredith $^{4,5} \cdot$ Kathy H. Hodder $^{1}$
}

Received: 8 October 2020 / Accepted: 24 May 2021 / Published online: 5 June 2021

(c) The Author(s) 2021

\begin{abstract}
Island populations may have a higher extinction risk due to reduced genetic diversity and need to be managed effectively in order to reduce the risk of biodiversity loss. The Eurasian red squirrels (Sciurus vulgaris) in the south of England only survive on three islands (the Isle of Wight, Brownsea and Furzey islands), with the Isle of Wight harbouring the largest population in the region. Fourteen microsatellites were used to determine the genetic structure of red squirrel populations on the Isle of Wight, as well as their relatedness to other populations of the species. Our results demonstrated that squirrels on these islands were less genetically diverse than those in Continental mainland populations, as would be expected. It also confirmed previous results from mitochondrial DNA which indicated that the squirrels on the Isle of Wight were relatively closely related to Brownsea island squirrels in the south of England. Importantly, our findings showed that genetic mixing between squirrels in the east and west of the Isle of Wight was very limited. Given the potential deleterious effects of small population size on genetic health, landscape management to encourage dispersal of squirrels between these populations should be a priority.
\end{abstract}

Keywords Sciurus vulgaris $\cdot$ Population structure $\cdot$ UK $\cdot$ Island populations · Conservation

Emilie A. Hardouin

ehardouin@bournemouth.ac.uk

1 Department of Life and Environmental Sciences, Faculty of Science and Technology, Bournemouth University, Dorset, UK

2 Wight Squirrel Project, Isle of Wight, UK

3 Institute of Novel and Emerging Infectious Diseases, Friedrich-Loeffler-Institut, Federal Research Institute for Animal Health, Südufer 10, 17493 Greifswald - Insel Riems, Germany

4 Royal (Dick) School of Veterinary Sciences, Easter Bush Campus, University of Edinburgh, Midlothian, UK

5 Faculty of Veterinary and Agricultural Sciences, Parkville Campus, The University of Melbourne, Melbourne, VIC, Australia

6 German Center for Infection Research (DZIF), Partner Site Hamburg-Lübeck-Borstel-Insel Riems, Greifswald-Insel Riems, Germany

\section{Introduction}

Island populations are often characterised by small population size, strong genetic differentiation and high genetic drift (Nei et al. 1975; Frankham 1997). Such populations may have higher extinction risks because of their low genetic diversity, due to founder effect and bottleneck events, which can cause inbreeding depression and limit their adaptive potential (Reed and Frankham 2003; Frankham 2005). As the Eurasian red squirrel (Sciurus vulgaris) in the south of the UK has been confined to islands and increasingly isolated woodland fragments, for around half a century (Lloyd 1983), these genetic factors are of particular concern (Hardouin et al. 2019).

The decline of the Eurasian red squirrel in the UK, following the introduction of its invasive congener, the Eastern grey squirrel Sciurus carolinensis, is well documented (e.g. Shorten 1953; Lloyd 1983; Kenward and Holm 1989; Gurnell and Pepper 1993; Gurnell et al. 2004) and the need to conserve remaining populations of the native species has been amplified by the establishment of $S$. carolinensis in parts of continental Europe (Bertolino et al. 2008, 2014). 
In the UK, the remaining strongholds for the native squirrel are found in large isolated woodlands in the north of England and southern Scotland, as well as still extensive, contiguous areas in northern Scotland. In the south of the country, the only remaining populations survive in parts of Wales (Ogden et al. 2005) and on three islands off the south coast of England (Brownsea and Furzey islands and the Isle of Wight-Rushton et al 1999; Hardouin et al 2019). Mitochondrial (mt) DNA analyses have revealed that red squirrels on the three islands have relatively low genetic diversity, appear more closely related to other British squirrels than to red squirrels from elsewhere in Europe, and tantalisingly, appeared to have private haplotypes indicating the potential presence of distinct genetic lineages on the islands (Hardouin et al. 2019).

With an estimated 3300 squirrels, the Isle of Wight (38,016 ha with over 3600 ha of woodland), harbours by far the largest population of red squirrels in the south of the country (Pope and Grogan 2003) with much smaller populations remaining on Brownsea and Furzey islands (Thain and Hodder 2015). As the islands are relatively safe from invasion by $S$. carolinensis, there is considerable justification for ensuring effective conservation management (including genetic diversity) of the red squirrel in these island strongholds. This arboreal specialist has maintained its presence on the Isle of Wight despite severe fragmentation of the woodland, especially in the south of the island (Rushton et al. 1999).

As habitat fragmentation has long been recognised as one of the main factors leading to biodiversity loss (e.g. Fahrig 2003), effective management requires understanding the impacts of habitat loss and fragmentation on species of conservation concern (Mortelliti et al. 2011). Studies of populations of red squirrels in fragmented landscapes have shown that woodland patch size, distance to other woodlands and dispersal corridors are all important to their distribution (Van Apeldorn et al. 1994), and that habitat quality strongly affects female space use (Verbeylen et al. 2009). It has also been recognised that fragmentation of woodlands affects the genetic population structure of red squirrels in Germany (Wiegand and Schröpfer 1997) and Belgium (Wauters et al. 1994). So, a lack of mixing between isolated populations might be expected to deleteriously affect the squirrels on the island and the ability of squirrels to disperse between patches is therefore crucial.

In common with most terrestrial mammals, dispersal of tree squirrels tends to occur by movement of juveniles from their natal ranges (Bosch and Lurz 2012) with distances of under $1 \mathrm{~km}$ typically recorded for red squirrels (e.g. Wauters et al. 2010), although much longer distances have been observed in low density forest habitats (Hämäläinen et al. 2019). In the highly modified landscape of the Isle of Wight, with only $12 \%$ of the island being afforested (Watts et al.
2016), such dispersal may be constrained. Past modelling of the persistence of squirrel populations on the island has emphasised the need for large and interconnected woods with management to enhance landscape features for dispersal and local population persistence (Rushton et al. 1999).

Hämäläinen et al. (2019) suggested that while movement patterns of dispersing red squirrels may be strongly influenced by landscape structure, they speculated that there may be little impact on gene flow in the forest landscape of Finland. In fragmented landscapes, this is likely to be true up to certain thresholds of habitat loss as postulated by Andren (1994) and provided that landscape features do not introduce impenetrable barriers (Trizio et al. 2005).

Building on previous research (Hardouin et al. 2019), this study therefore focuses on the following aims in order to inform both local and regional conservation strategies for this charismatic rodent: (i) to characterise the genetic structure and diversity of the red squirrel population on the Isle of Wight in order to determine whether there is evidence that the fragmented woodlands impede gene flow, (ii) to determine whether microsatellite analyses support conclusions from mtDNA on the relatedness of the island squirrels to other island and mainland populations.

\section{Materials and methods}

\section{Samples}

The sampling scheme used to obtain DNA for Brownsea red squirrels is described in Hardouin et al. (2019). Arran red squirrel tissue samples were collected opportunistically from road kills. Ear tissue samples from the Isle of Wight were collected between 2013 and 2018 as part of the Wight Squirrel Project monitoring program (see Simpson et al. 2013a for sampling scheme). The general public from all around the island were encouraged to report red squirrel deaths and the carcasses were sampled for the DNA extraction. Samples from Germany originate from wildlife rescue centres and zoological gardens in Bavaria and Baden-Wuerttemberg, southern Germany (Fig. 1).

\section{Microsatellite genotyping}

Microsatellites described in Todd et al. 2000 and Hale et al. 2001a were tested and 161 red squirrel samples were successfully genotyped for 15 markers. The 5' end of the forward primers was labelled with either HEX or FAM dyes. All reactions were carried out in $13 \mu \mathrm{l}$ volumes using $10 \mathrm{ng}$ of DNA template. Primer pairs were mixed in 7 pools and reactions were performed using the QIAGEN multiplex PCR kit. PCR conditions were as follow: $94{ }^{\circ} \mathrm{C}$ for $5 \mathrm{~min}$, then 35 cycles of denaturation $\left(94{ }^{\circ} \mathrm{C}\right.$ for $30 \mathrm{~s}$ ), annealing (for $30 \mathrm{~s}$ 


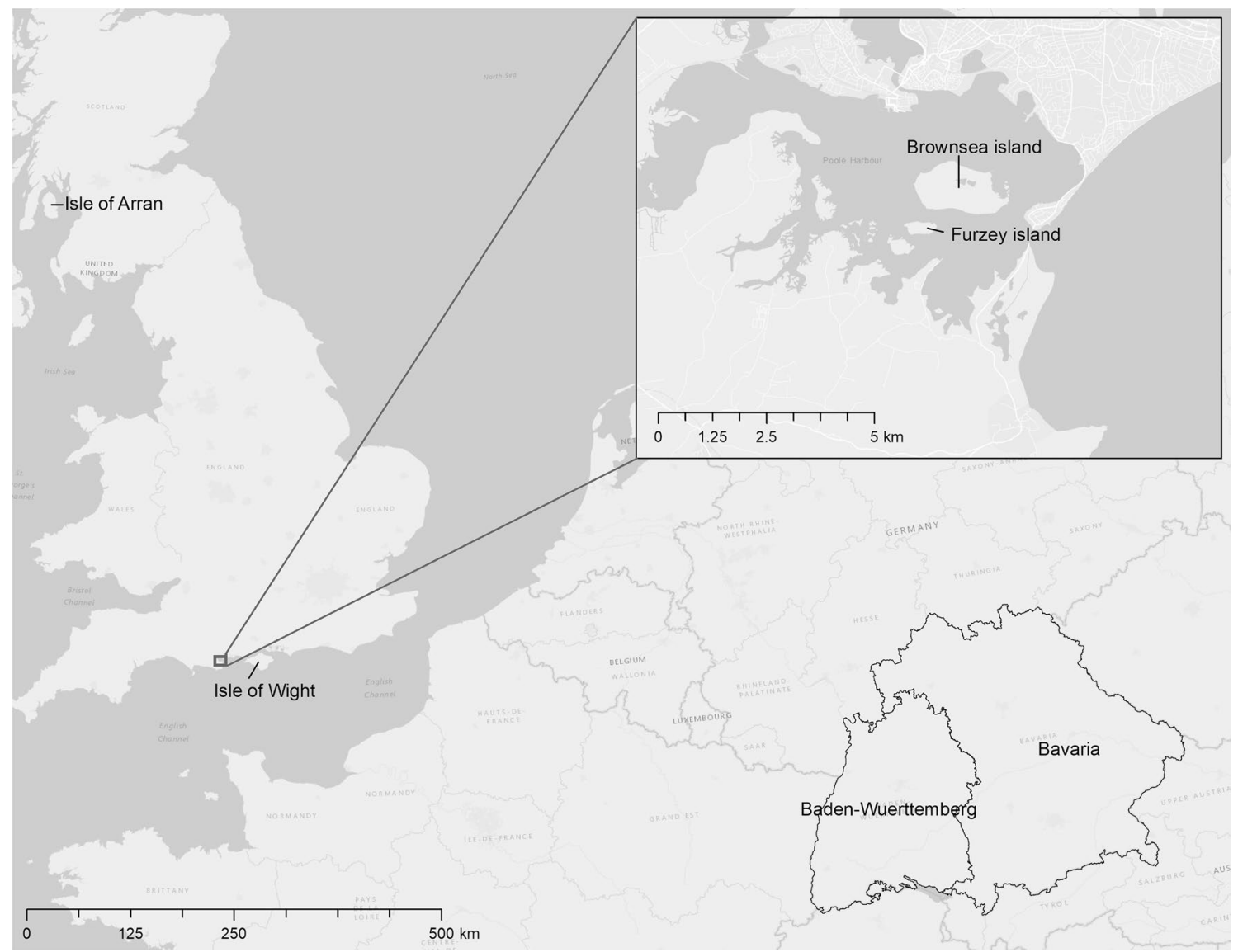

Fig. 1 Map of the study area with sampling locations in the UK and Germany

at $52{ }^{\circ} \mathrm{C}$ or to $54{ }^{\circ} \mathrm{C}$ depending on primer pool), and then amplification $\left(72{ }^{\circ} \mathrm{C}\right.$ for $1 \mathrm{~min}$ ), followed by a final elongation at $72{ }^{\circ} \mathrm{C}$ for $10 \mathrm{~min}$.

\section{Microsatellite analysis}

Calculation of the observed and expected heterozygosity, and the average number of alleles per locus was performed with GENETIX (Belkhir et al. 2004) for each population. The Hardy-Weinberg equilibrium and Fst were tested using Arlequin (Excoffier and Lischer 2010). Allelic richness was calculated using the PopGenReport (Adamack and Gruber 2014). Fis was investigated using diveRsity and 1000 bootstraps were used to infer the $95 \%$ confidence intervals (Keenan et al. 2013). Then discriminant analysis of principal components (DAPC) (Jombart et al. 2010) was used to assess the population structure using the complete dataset. DAPC and Monnonier's analysis were performed in R using the ADEGENET package (Jombart et al. 2008). DAPC is a multivariate analysis which inferred the probability of individual membership in each different group. The program covered a range of possible clusters from 1 to 10 . The interaction number used was 1,000,000,000. 30 principal components, explaining $92.4 \%$ of the total variance, were retained as predictors for discriminant analysis.

In addition, we performed a structure analysis on the entire dataset using STRUCTURE software (Pritchard et al. 2000) with a burn-in period of 250,000 simulations followed by a run length of 750,000 Markov chain Monte Carlo (MCMC) simulations and ten iterations for each $\mathrm{K}$ (number of clusters) with the admixture model. The results were analysed using STRUCTURE HARVESTER (Earl and vonHoldt 2012) and the $\mathrm{K}$ was chosen using a combination of Evanno's criteria (Evanno et al. 2005) and investigating run convergence using CLUMPP (Jakobsson and Rosenberg 2007). Results were summarized using CLUMPP (Jakobsson and Rosenberg 2007) and drawn using Distruct (Rosenberg 2004). K from 1 to 10 was tested for the entire dataset (6 populations and 161 individuals). The data set was further spit in two: the Isle of Wight for which $K=1$ to $\mathrm{K}=7$ were tested and the rest of the populations (Brownsea, Arran, Baden-Wuerttemberg and Bavaria) for which $\mathrm{K}=1$ to $K=10$ were tested. Isolation by distance (IBD) for the Isle of Wight was investigated using Mantel test provided in the Adegenet package (Jombart et al. 2008). The potential for bottlenecks on the Isle of Wight was investigated using 
BOTTLENECK (Piry et al. 1999). Effective population size $(\mathrm{Ne})$ was estimated for the population on the Isle of Wight using NeEstimator V2.1 (Do et al. 2014). IBD, bottleneck and Ne were not calculated for the other populations as sample sizes were insufficient.

\section{Spatial distribution and land cover}

In order to determine whether the sample of squirrel carcasses from the Isle of Wight might be biased towards where people live and are hence more likely to be found, we determined the broad habitat for sample locations. The habitat categories from the Centre for Ecology and Hydrology Land Cover Map 2015 (2017) were merged to five broad classes: (1). Arable and horticulture $26.2 \%$, (2). Grasslands (consisting of all sub-types of grasslands) $46.5 \%$, (3). Woodland (broadleaf and coniferous woodland) $12.1 \%$, (4). Urban and suburban $2.1 \%$ and (5). Other (merging all remaining categories, predominantly coastal littoral, saltwater and saltmarsh) $13.1 \%$ of the total area. Subsequently, the study area was divided into 48 equally sized rectangles $\left(10 \mathrm{~km}^{2}\right)$ and the percentage of all land cover categories and the number of squirrel carcasses retrieved in this study was calculated for each rectangle. Spearman rho and Kendall tau was used to establish correlation between land cover types and squirrel numbers. Multiple buffer ring analysis was also employed to investigate the relationship between the location of squirrel carcasses and the distance from settlements on the Isle of Wight (Office for National Statistics, 2011 Census data, ons.gov.uk). A series of buffers at $500 \mathrm{~m}, 1000 \mathrm{~m}, 1500 \mathrm{~m}$, $2000 \mathrm{~m}, 2500 \mathrm{~m}, 3000 \mathrm{~m}$ and $3500 \mathrm{~m}$ were created around 21 areas with the highest population density. All spatial analyses used ArcMap 10.1.

\section{Results}

\section{Genetic diversity}

Out of the 15 microsatellites, one was found not under Hardy-Weinberg equilibrium and it was therefore excluded from the analysis. Samples with less than $70 \%$ of microsatellites successfully amplified were also excluded; therefore, the final dataset was composed of 161 individuals. As expected, mean allelic richness was found to be higher in Continental mainland populations (4.34 for Baden-Wuerttemberg, 4.37 for Bavaria) when compared to the islands (2.22 for Isle of Arran, 2.28 for Brownsea Island and 2.69 for the Isle of Wight-Table 1). Fis were calculated for all of our populations (Table 1), and no deficit or excess of heterozygotes was found apart from the Isle of Wight (Fis $=0.132,0.08 ; 0.1895 \%$ CI). However, these positive Fis values are likely to be related to the two distinct genetic clusters that were found on this island (i.e., a Wahlund effect).

\section{Population structure}

The lowest Bayesian information criterion (BIC) value (194.86) was found for $\mathrm{K}=7$ in the DAPC analysis. The first 30 PCs of principal component analysis (PCA) explaining $92.4 \%$ of the total variance were kept. The first two axes represent respectively $48 \%$ and $26 \%$ of the variance (Fig. 2). Axis 1 explained the variation between Arran and the rest of the populations. The South German and the UK populations are separated on axis 2. The Isle of Wight and Brownsea Island group together and Bavaria and Baden-Wuerttemberg also form a group of two (Fig. 2).

The population structure of the dataset was further investigated using STRUCTURE (Pritchard et al. 2000). $K=2$ was selected as the best model for the entire dataset and in this model the Isle of Wight was found to be genetically distinct from the rest of the populations (Fig. 3a).

When population structure on the Isle of Wight was investigated separately this indicated that the island population is separated into two different clusters (Fig. 3b). The Evanno's method suggests that $\mathrm{K}=3$ is the appropriate $\mathrm{K}$ (Fig. 3b) however, increasing the number of $\mathrm{K}$ only divides one of the clusters (Fig. 3b), therefore $\mathrm{K}=2$ was chosen as the best $\mathrm{K}$ to explain the data. The island appears to harbour two genetically different populations, one located in the west and the other on the east of the island (Fig. 4).

Table 1 Population genetic parameters for the 14 microsatellite loci used in this study: N number of samples, Hexp: expected heterozygosity, Hobs: observed homozygosity, SD: standard deviation, Ao: average number of allele per locus, CI: confidence intervals

\begin{tabular}{|c|c|c|c|c|c|c|c|c|c|c|c|}
\hline \multirow[t]{2}{*}{ Country } & \multirow[t]{2}{*}{ Population } & \multirow[t]{2}{*}{$\mathrm{N}$} & \multirow[t]{2}{*}{ Hexp } & \multirow[t]{2}{*}{ SD } & \multirow[t]{2}{*}{ Hobs } & \multirow[t]{2}{*}{ SD } & \multirow[t]{2}{*}{ Ao } & \multirow{2}{*}{$\begin{array}{l}\text { Mean allelic } \\
\text { richness }\end{array}$} & \multirow[t]{2}{*}{ Fis } & \multicolumn{2}{|l|}{$95 \% \mathrm{CI}$} \\
\hline & & & & & & & & & & Lower & Upper \\
\hline \multirow[t]{3}{*}{ UK } & Isle of Arran & 11 & 0.43 & 0.15 & 0.40 & 0.20 & 2.29 & 2.22 & 0.054 & -0.16 & 0.22 \\
\hline & Brownsea Island & 11 & 0.36 & 0.21 & 0.35 & 0.25 & 2.50 & 2.28 & 0.029 & -0.16 & 0.19 \\
\hline & Isle of Wight & 117 & 0.40 & 0.24 & 0.35 & 0.22 & 3.79 & 2.69 & 0.132 & 0.08 & 0.18 \\
\hline \multirow[t]{2}{*}{ Germany } & Baden-Wuerttemberg & 8 & 0.65 & 0.18 & 0.69 & 0.23 & 5.00 & 4.34 & -0.073 & -0.20 & 0.01 \\
\hline & Bavaria & 14 & 0.66 & 0.14 & 0.68 & 0.24 & 5.36 & 4.37 & -0.026 & -0.11 & 0.05 \\
\hline
\end{tabular}


Fig. 2 Representation of the variation of 14 microsatellites on the first two axes of a discriminant analysis of principal components (DAPC). The percentage of the total eigenvalue explained by axis 1 is $48 \%$ and for axis $2,26 \%$. IoW, Isle of Wight

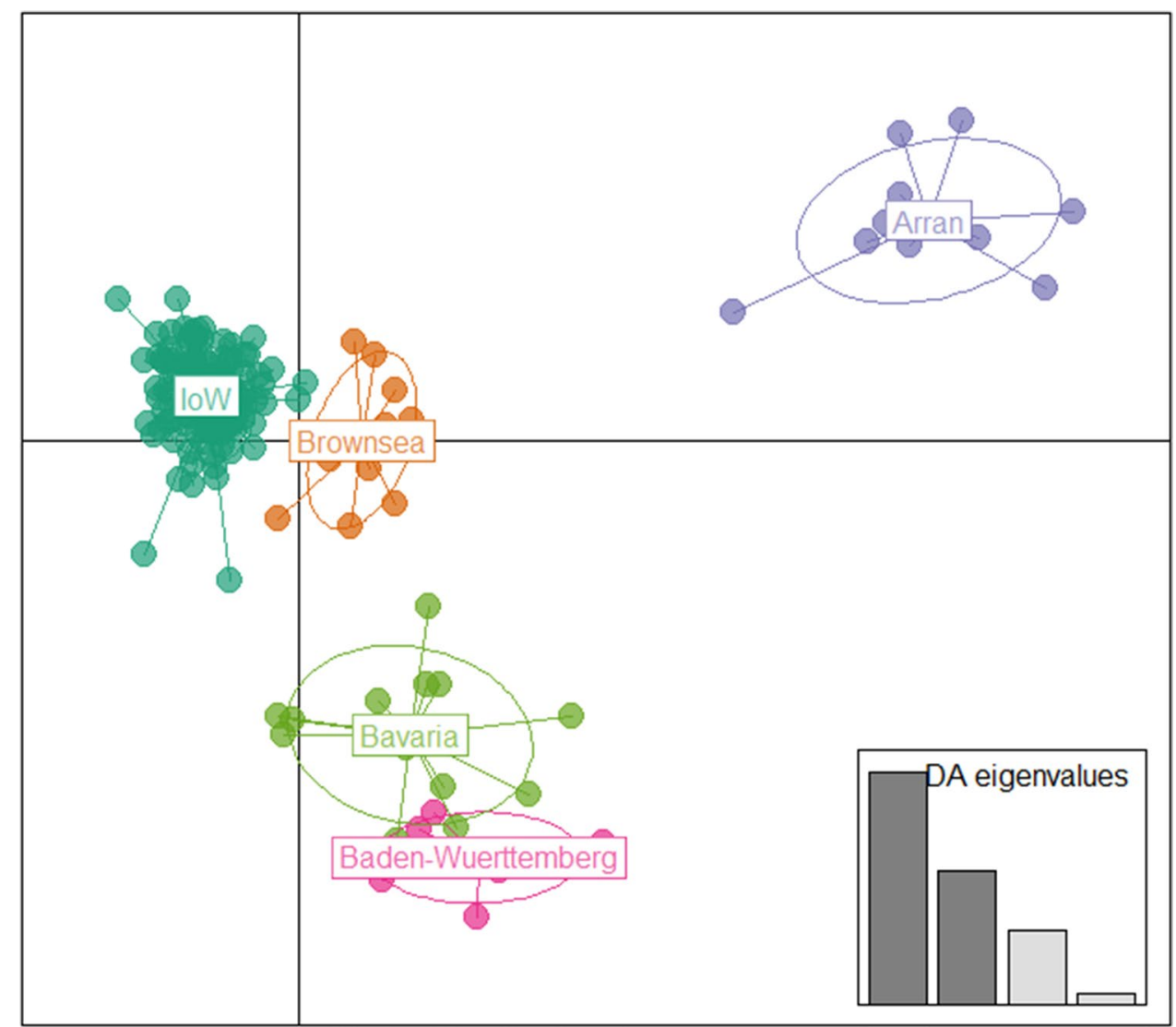

The genetic structure of the four remaining populations was further tested and even though the best $\mathrm{K}$ was found to be $\mathrm{K}=2$ using the Evanno method, further inspection of the results using CLUMPP reveals that $\mathrm{K}=2, \mathrm{~K}=3$ and $\mathrm{K}=4$ did not converge. $K=5$ was found to converge and to give the best fit to the data (Fig. 3c). In this analysis, Brownsea and Arran islands displayed genetic signatures that were distinct from each other, and the two South German populations clustered together (Fig. 3c). The German population structure was investigated further using structure and again it was not possible to differentiate them (supplementary material 1A). A 3D factorial was also generated, axis 1 was found to explain $100 \%$ of the variation and differentiate both populations (supplementary material 1B).

Pairwise Fst between all those populations was calculated and was found to be between 0.18 and 0.45 with a significant p-value except between the two German populations ( $\mathrm{Fst}=0.01, \mathrm{p}=0.23$-Table 2). A Mantel test was performed for the Isle of Wight and the geographical and genetic matrices were found to be positively correlated $(0.372, p=0.0001)$. There were insufficient numbers of samples to conduct this test for the remaining sites.

Genetic boundaries on the Isle of Wight were investigated further using Monnonier's algorithm (Fig. 5) which identifies the centre of the island, as well as small proportion of the coast, as forming a genetic barrier (Fig. 5).

\section{Bottleneck and effective population size on the Isle of Wight}

$\mathrm{Ne}$ and the probability of a recent bottleneck was investigated on both parts of the Isle of Wight. No sign of a bottleneck was found on the island under the SMM (Step Mutation Model) using a Wilcoxon test $(\mathrm{p}=0.83$ and $\mathrm{p}=0.90$ for the west and the east of the island respectively). Ne was found to be 40.3 for the western part of the Isle of Wight and 73.7 for the eastern part of the island using the linkage disequilibrium method with a frequency threshold of 0.05 . Fis was calculated for both populations on the Isle of Wight. Fis was found to be $0.061(-0.031 ; 0.151,95 \% \mathrm{CI})$ and 0.067 $(0.013 ; 0.122,95 \% \mathrm{CI})$ for the west and the east population respectively revealing a signature of inbreeding in the Eastern population on the Isle of Wight.

\section{Testing the sampling validity for S. vulgaris on the Isle of Wight}

Red squirrels obtained from the Isle of Wight for this study were sampled by the general public and so we tested the spatial distribution of the samples to determine whether any bias toward location of samples in, or close to, settlements might have affected our data. Multiple buffer ring analysis indicated that the highest concentrations of red 
Fig. 3 Structure results for S. vulgaris populations. a Structure results for the entire dataset. As $K=2$ was found to the best $\mathrm{K}$, the dataset was further split into two: the Isle of Wight (b) and the rest of the populations (c)
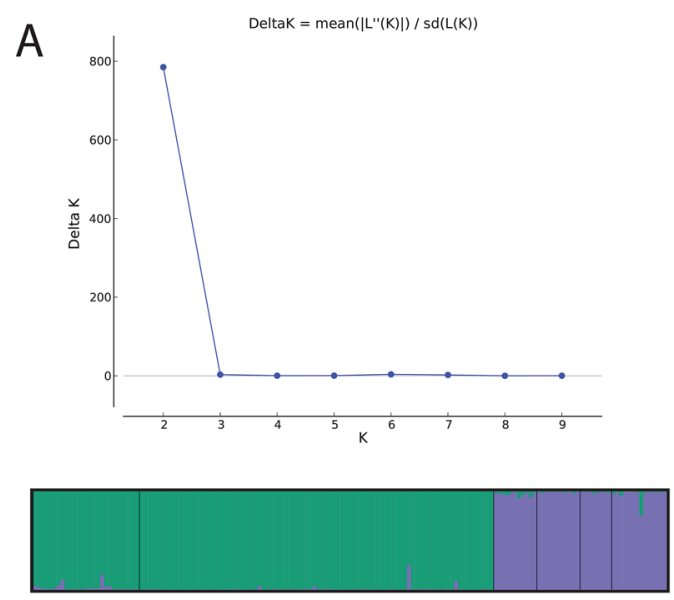

$\mathrm{K}=2$
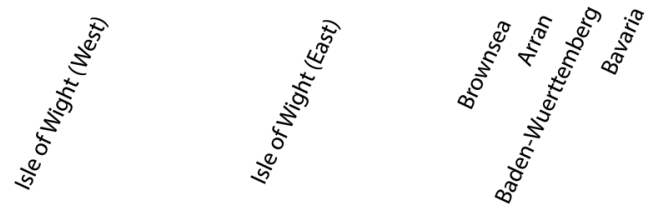

B
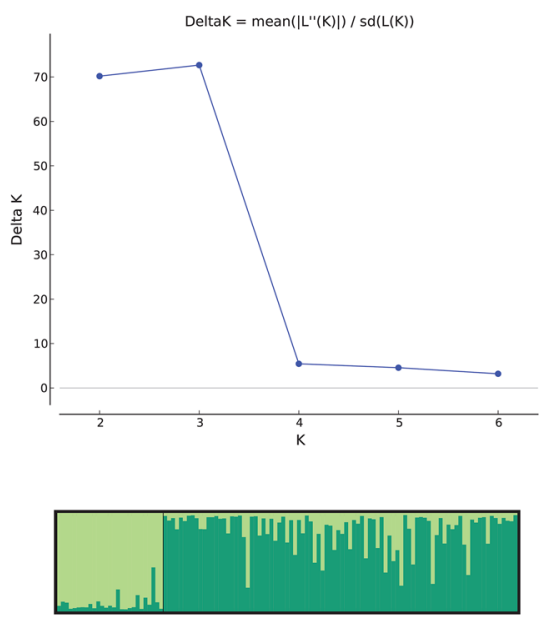

$\mathrm{K}=2$

C
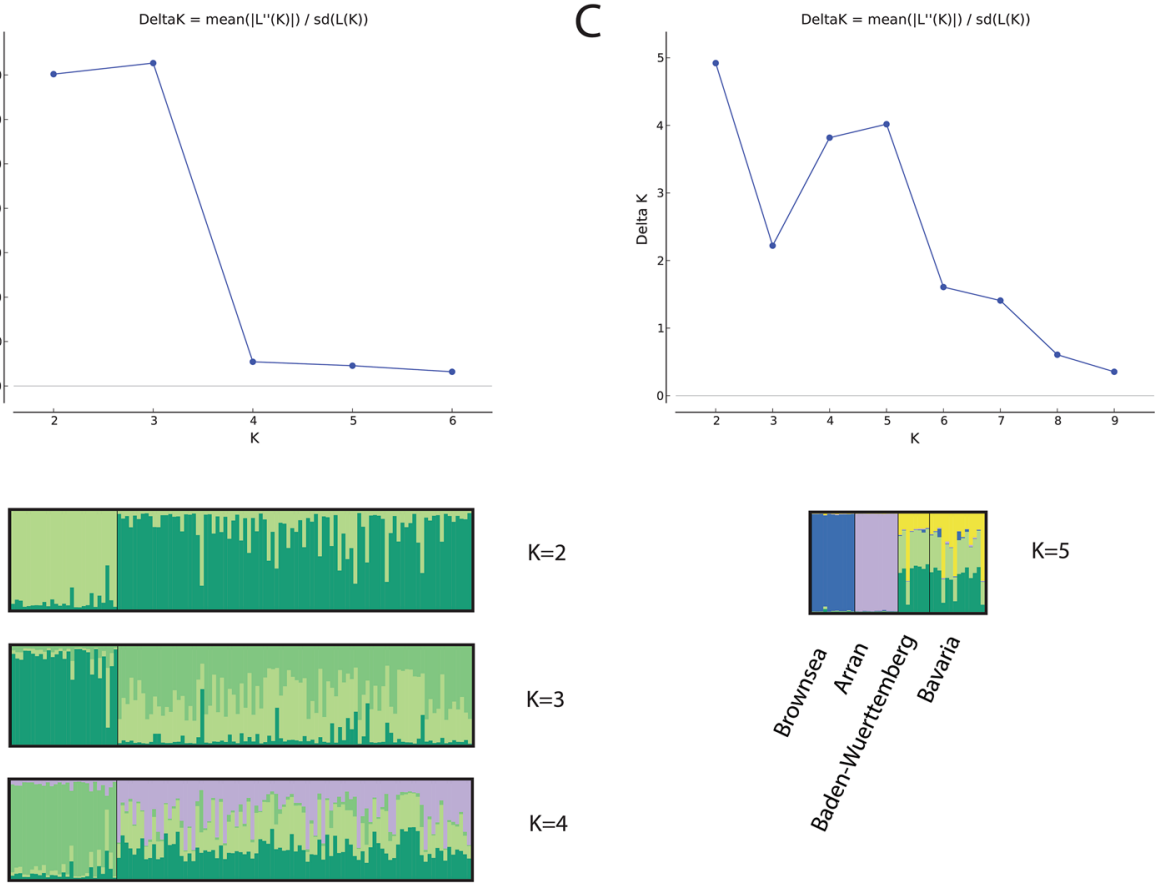

$K=3$

$K=4$

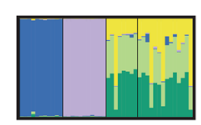

$K=5$

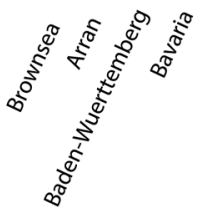

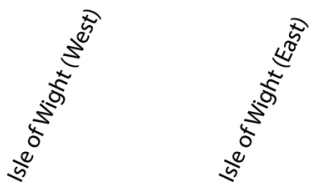

squirrels sampled on the Isle of Wight were in close proximity to human settlements (Fig. 6). $40 \%$ of all red squirrel sightings were recorded within $500 \mathrm{~m}$ of the outer perimeter of the settlements, while only $21 \%$ are recorded at a distance of $2000 \mathrm{~m}$, or more, from the outer perimeter of the settlements. The association between red squirrels and land cover was also tested, and no association was found between red squirrel data locations and urban land cover class. The only significant correlation between land cover type and red squirrel carcass locations was with woodland (Spearman's Rho $=0.34, \mathrm{p}<0.05$, Kendall Tau $=0.27$, $\mathrm{p}<0.05)$. 


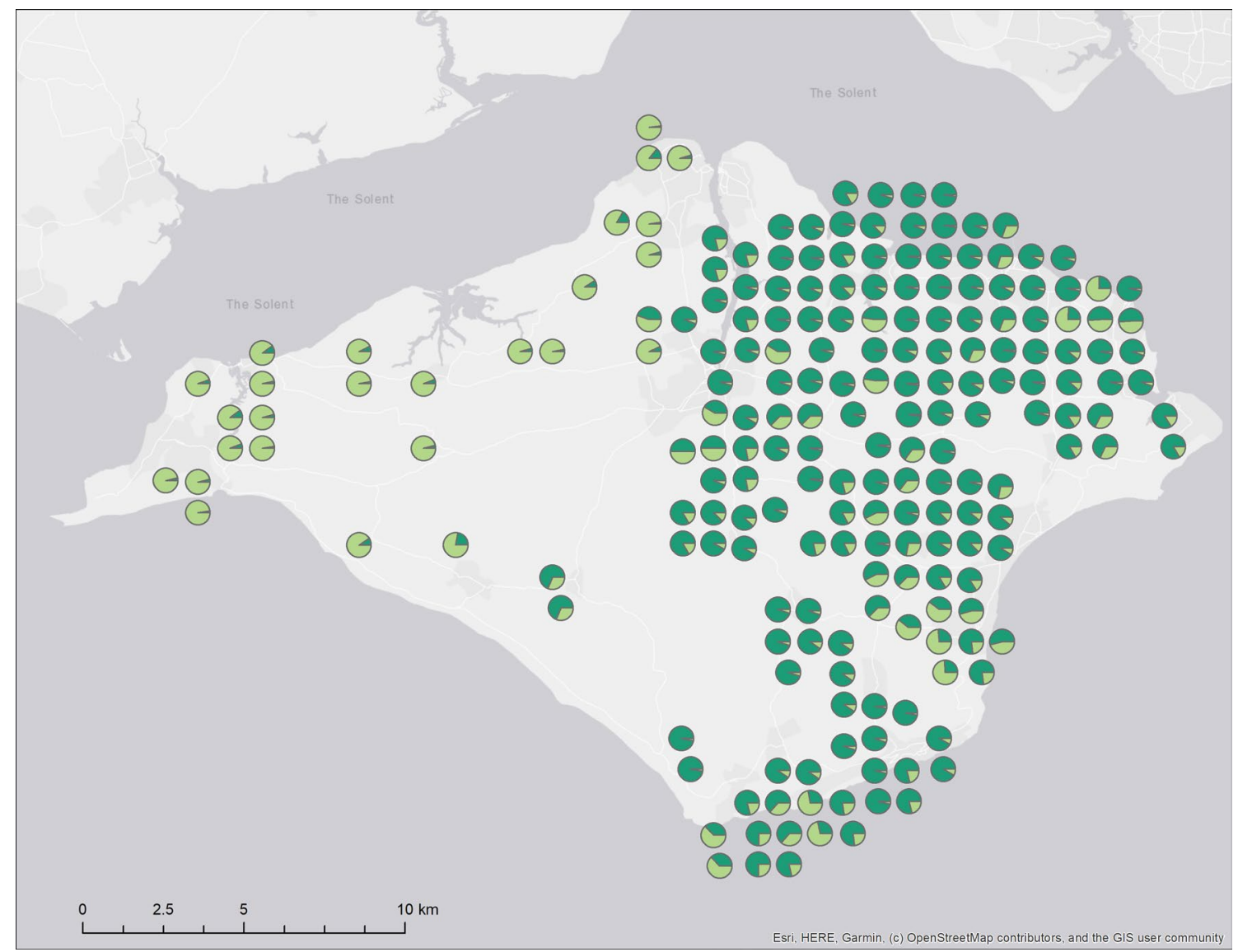

Fig. 4 Geographical location of the two different genetic populations on the Isle of Wight found with the STRUCTURE analysis. Each pie chart represents an individual squirrel with the percentage of each of the two genetic populations defined using the STRUCTURE analysis

Table 2 Pairwise Fst values for 14 microsatellites for red squirrel populations from the British islands and south German populations

\begin{tabular}{lccccc}
\hline & Isle of Wight & Brownsea Island & Isle of Arran & $\begin{array}{l}\text { Baden- } \\
\text { Wuerttem- } \\
\text { berg }\end{array}$ & Bavaria \\
\hline Isle of Wight & - & & & \\
Brownsea Island & $\mathbf{0 . 3 5}$ & - & - & - \\
Isle of Arran & $\mathbf{0 . 4 5}$ & $\mathbf{0 . 3 1}$ & $\mathbf{0 . 2 1}$ & -0.01 & - \\
Baden-Wuerttemberg & $\mathbf{0 . 3 3}$ & $\mathbf{0 . 2 0}$ & $\mathbf{0 . 2 3}$ & \\
Bavaria & $\mathbf{0 . 2 8}$ & $\mathbf{0 . 1 8}$ & & & \\
\hline
\end{tabular}

Significant $\mathrm{p}$ values are highlighted in bold

\section{Discussion}

Our results indicated a clear fragmentation of the red squirrel populations on the Isle of Wight. This reinforces previous conclusions from spatially explicit population dynamics modelling (Rushton et al. 1999) that landscape management to provide dispersal corridors and to interconnect woodlands is critical for the long term future of the species on the island.
We also found relatively low genetic diversity for the island in comparison to continental squirrels. However, no genetic bottleneck was detected on the Isle of Wight. It is worth noting that low genetic diversity has also been reported for other red squirrel populations in the UK when they are compared to continental populations using Major Histocompatibility Complex (MHC) class II (Ballingal et al. 2016) and when using mtDNA (Baratt et al. 1999; Hale et al. 2004; Ogden et al. 2005). Our results also supported previous findings from mtDNA, indicating that the Isle of Wight population is genetically close 
Fig. 5 Genetic boundaries inferred using Monnonier's algorithm. The thick black line represents the barrier to gene flow

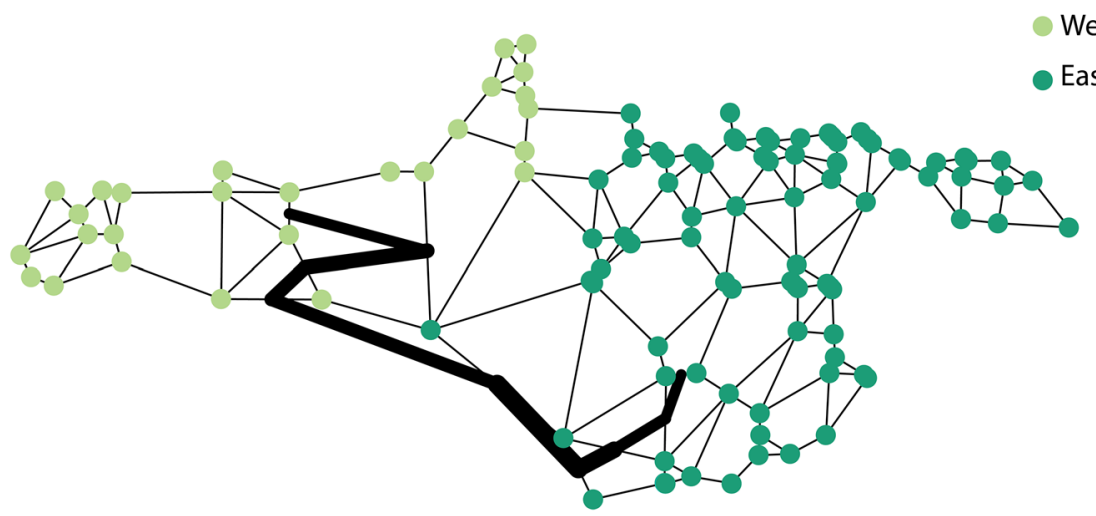

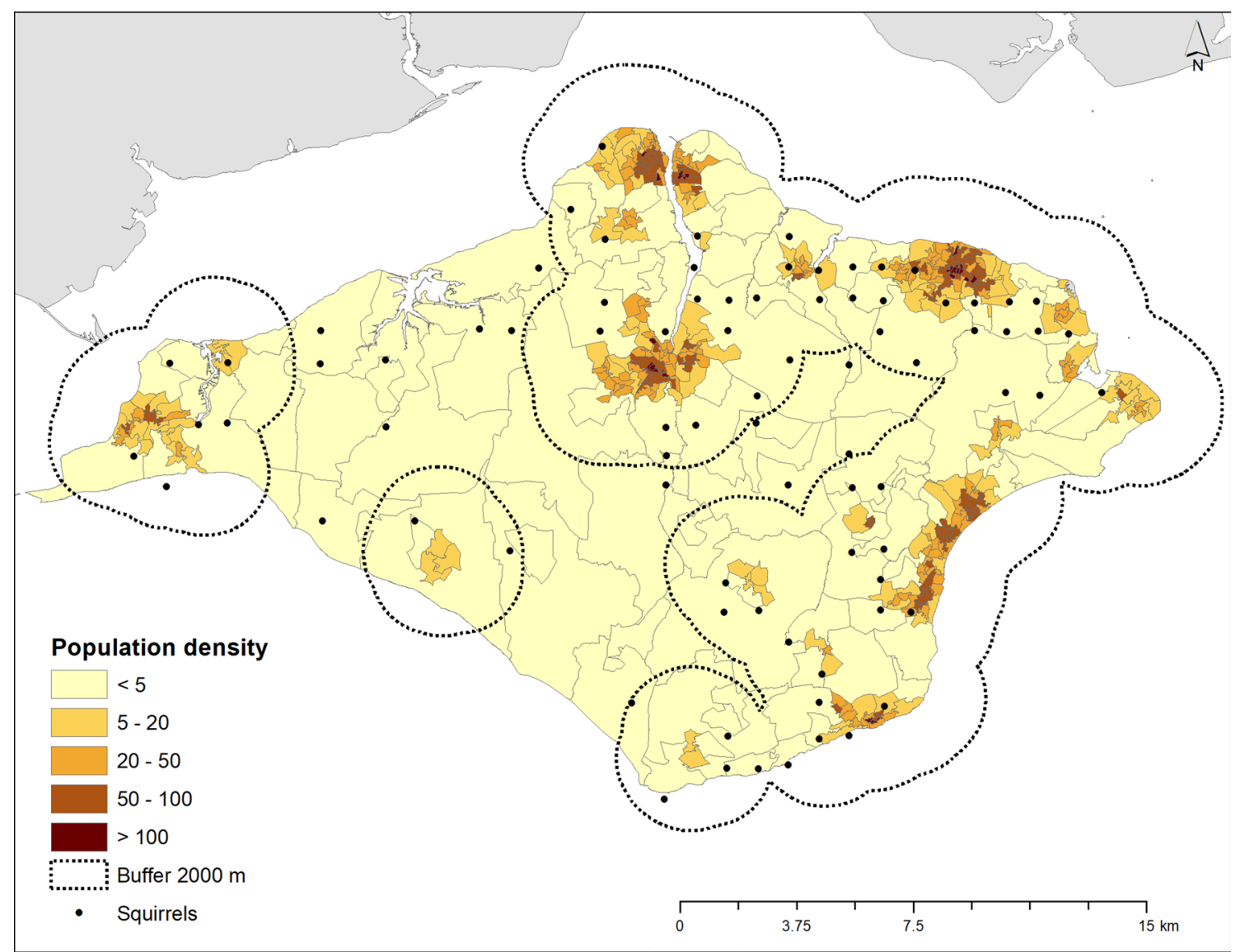

Fig. 6 Human population density on the Isle of Wight. Black dots represent the geographical location of the squirrel carcasses used in this study 
to the Brownsea Island population, which probably reflects a common origin, and that those island populations share unique haplotypes when compared to a European dataset (Hardouin et al. 2019).

\section{Population structure and connectivity on the Isle of Wight}

As $S$. vulgaris is an arboreal specialist, with a preference for closed canopy (Gurnell et al. 2002; Samaras and Youlatos 2010), it is unsurprising that fragmentation of woodland habitats has been shown to affect the genetic diversity of red squirrels (Wauters et al. 1994; Hale et al. 2001b; Trizio et al. 2005; Simpson et al. 2013b; Rézouki et al. 2014; O’Meara et al. 2018). Our findings suggest that this impediment to gene flow may also be true for squirrels on the Isle of Wight. Our assessment of the distribution of the red squirrel samples did indicate that they tended to be found relatively close to human settlement. This result is expected as the squirrels have been collected with the help of the general public for the Wight Squirrel Project monitoring program (Simpson et al. 2013a) and this influenced sample locations. Relatively few samples were collected from the centre of the island where human density is low (Fig. 5) and this could represent a potential sampling error. Nevertheless, the East/West population structure that we found seems likely to be associated with the pattern of woodland cover on the island. Most of the larger patches of woodland, which are most likely to harbour larger populations of squirrels (Van Apeldoorn et al. 1994) are situated to the East and West, with only small, isolated woodlands in the centre (Rushton et al. 1999, Fig. 5) which was found to reprensent a barrier to gene flow. It may be pertinent that the landscape on the island has been highly modified since early history and, that there is thought to be more woodland on the island now than there has been for hundreds of years (IWBP 2009).

The regeneration of woodland on the island in recent decades, such as by the Forestry Commission funded JIGSAW project (Quine and Watts 2007), should provide opportunities for creatively managing the landscape connectivity for the red squirrel and other woodland specialists. Although it is important to note that the benefits of landscape connectivity cannot necessarily be assumed for all woodland specialists (Watts et al. 2016). Rushton et al. (1999) recommended maintaining large woodlands, which can act as population sources, and ensuring the presence of habitat corridors, such as hedgerows, in order to conserve the red squirrels on the Isle of Wight. Since then, the importance of habitat corridors in the restoration of genetic mixing for red squirrels has been demonstrated (Hale et al. 2001b; Trizio et al. 2005).

Although, the importance of corridors for red squirrels is clear, the design of functional corridors is affected by muliple considerations: patch size and quality, matrix composition and barriers to dispersal. So, it will be important to understand the dispersal behaviour of the Isle of Wight red squirrels in order to understand the mechanisms underlying the population structure and to develop any measures that may be effective in enhancing genetic mixing. As the woodlands of the Isle of Wight are dominated by mixed woodlands providing a range of tree seed crops (Rushton et al. 1999), breeding dispersal would be expected to be relatively rare as this is generally a phenomenon of habitats with unreliable food sources (Lurz et al. 1997). Gene flow between woodland patches would most likely occur through dispersal of adult males in search of mates and young squirrels dispersing from their natal ranges (reviewed in Bosch and Lurz 2012). Given the wide range of dispersal distances that have been recorded for this species in fragmented landscapes (e.g. Wauters et al. 2010, Bosch and Lurz 2012, Hämäläinen et al. 2019), further work will be needed to determine the functionality of apparent landscape corridors, the potential for natal dispersal in the Isle of Wight, and how this might be enhanced. The permeability of the matrix and presence of barriers will also be important factors (Trizio et al. 2005). Although roads appeared not to be a barrier for the dispersal of red squirrels in an urban environment (Fey et al. 2016) other studies have shown that road crossing can be a major cause of mortality (Simpson et al. 2013a on the Isle of Wight, LaRose et al. 2010 in Scotland). Given that the tendency for red squirrels to cross roads appears to be life stage and state specific (Fey et al. 2016), there might be potential to manage particular crossing points when juvenile dispersal is at its most prevalent. Appropriate bridges to connect woodlands fragmented by roads can also benefit other wildlife, such as the hazel dormouse Muscardinus avellanarius (White and Hughes 2019).

Another possible barrier to gene flow on the Isle of Wight could be the Medina river in the north of the island (Fig. 6). Even though red squirrels are able to swim (Kenward and Hodder 1998, Bosch and Lurz 2012), it would be likely to decrease gene flow. For example, in Ireland the river Shannon has been found to act as a barrier for the migration of grey squirrels even if some individuals were occasionaly able to swim across (Carey et al. 2007). However, the river Medina is only $17 \mathrm{~km}$ long, therefore, its impact is likely to be limited.

\section{Phylogeographic structure}

Red squirrels in Europe have been found to lack phylogeographical structure when using mitochondrial DNA (Barrat et al. 1999; Grill et al. 2009; Hardouin et al. 2019). In contrast, microsatellite techniques used here demonstrated a clear population structure despite using a modest number of markers. We showed that the population of Brownsea Island 
and Isle of Wight are genetically closer to one another than to the Isle of Arran population (Scotland), whereas the two mainland populations from southern Germany were genetically similar to each other. This result suggests that nuclear markers might help us to understand the evolutionary history of the species. Such a lack of genetic structure in mtDNA when compared to nuclear markers is not uncommon and has been found in several species such as the red fox (Vulpes vulpes) for example (Teacher et al. 2011; Statham et al. 2018; McDevitt et al. 2020).

Allelic richness in our samples was found to be higher in mainland populations when compared to islands, which is expected (Nei et al. 1975). In small populations, there is a risk that alleles associated with better fitness might behave neutrally if genetic drift is stronger than natural selection (Wright 1931; Bouzat 2010). The protection of island populations is often a conservation priority due their unique genetic make-up, however, it can also lead to the risk of conserving an inbred population in order to conserve genetic uniqueness (Weeks et al. 2016). However, recent studies have demonstrated that adaptive differentation can act on islands even where strong drift occurs (Funk et al. 2016; Prentice et al. 2017). Therefore, understanding the role of genetic drift and natural selection in red squirrels on the Isle of Wight would be a critical step in order to infer if the loss of genetic diversity is a threat to the population and to develop an effective conservation strategy.

\section{Conservation of the Isle of Wight and Brownsea squirrel populations}

Previous work, using mtDNA, has shown that the last remaining red squirrel populations in the south of the England form two separate Evolutionary Significant Units (ESUs): (i) Isle of Wight and (ii) Brownsea/ Furzey combined as squirrels have been found to move between Brownsea and Furzey islands (Thain and Hodder 2015). Populations were also found to be genetically unique compared to 54 European populations using mtDNA markers (Hardouin et al. 2019). Here, our results supported those findings as we also found a high genetic divergence for those islands. Fst between Brownsea and the Isle of Wight was found to be 0.35 with $\mathrm{p}<0.05$ (Table 2). Nevertheless, they seem to be closely related to each other when compared to Isle of Arran and southern German populations (Fig. 2).

As genetic diversity on the Isle of Wight and Brownsea Island was found to be low using both mtDNA techniques (Hardouin et al. 2019) and microsatellites (this study), there could be concerns for the long term future of the population. No signs of inbreeding were found on Brownsea Island with our small dataset, however some sign of inbreeding was found in the Eastern population of red squirrels on the Isle of Wight. However, Ne on the Isle of Wight was only 40.3 in the west and 73.7 in the east. As $\mathrm{Ne}>1000$ is the value currently accepted as the minimum threshold to maintain adequate adaptive potential (Willi et al. 2006) the genetic health of the population requires ongoing monitoring. In terms of national strategy, it would be of particular interest to investigate the genetic structure of the British population further to identify possible rescue sources in case they are ever needed for these remnant populations of squirrels in the South of the UK. Ogden et al. (2005) employed this strategy by including donor squirrels from other areas to maximise genetic heterogeneity for conservation of red squirrels in Wales.

If genetic rescue by translocation of squirrels between Brownsea and the Isle of Wight was contemplated, this would require consideration of many risks including: outbreeding depression, loss of local adaptation, replacemenent of recipient genetic background and pathogen transmission (Week et al. 2011). The geographical and genetic similarity between the Isle of Wight and Brownsea populations would probably mean a very low risk of outbreeding depression, loss of local adaptation and replacement of genetic background. The main issue is likely to be the potential for pathogen transmission, for instance, Mycobacterium leprae causing leprosy is present on Brownsea Island and M. lepromatosis on the Isle of Wight (Avanzi et al. 2016).

Supplementary Information The online version contains supplementary material available at https://doi.org/10.1007/s10592-021-01380-z.

Acknowledgements We would like to thank the Wight Squirrel Project for commissioning the research as well as all the people of the Isle of Wight who helped collecting samples. The authors also would like to thank Korinna Seybold, Sabine Gallenberger, Jessica Hoch, Anette Hübsch, Sonja Jonas, Katharina Volk, Tobias Knauf-Witzens, Stefan Bosch and Jessica Weindl for collecting samples in southern Germany. We also would like to thank Kate Sampson, Corinna Goeckeritz, Andy Walker, Robert Logan, Angela Cott, Timothy Hartley, Nicki Tutton, Luke Johns, Chris Thain (National Trust for Scotland, Forestry Commission Scotland, National Trust Brownsea, Dorset Wildlife Trust) who were involved in the collection of samples on Brownsea Island and the Isle of Arran. The authors would also like to thank Alice Galligar for her help in the lab. We would also like to thank the three anonymous reviewers who helped to improve our manuscript.

Authors contribution EAH and HB conceived the study. HB, AKS, $\mathrm{AM}$ and PWWL conducted field work for this investigation. RGU and VS did collect samples, dissect and provide tissues samples. EAH conducted the laboratory work. EAH, MC and $\mathrm{KHH}$ conducted the data analysis. EAH and $\mathrm{KHH}$ wrote the final manuscript. All authors were involved in writing and data interpretation and read and approved the final manuscript.

Funding The work was commissioned by the Wight Squirrel Project.

Data availability Genotype data is provided as supplementary material in a genepop format. 


\section{Declarations}

Conflict of interest The author declares that they have no conflict of interest.

Open Access This article is licensed under a Creative Commons Attribution 4.0 International License, which permits use, sharing, adaptation, distribution and reproduction in any medium or format, as long as you give appropriate credit to the original author(s) and the source, provide a link to the Creative Commons licence, and indicate if changes were made. The images or other third party material in this article are included in the article's Creative Commons licence, unless indicated otherwise in a credit line to the material. If material is not included in the article's Creative Commons licence and your intended use is not permitted by statutory regulation or exceeds the permitted use, you will need to obtain permission directly from the copyright holder. To view a copy of this licence, visit http://creativecommons.org/licenses/by/4.0/.

\section{References}

Adamack AT, Gruber B (2014) Pop Gen Report : simplifying basic population genetic analyses in R. Methods Ecol Evol 5:384-387. https://doi.org/10.1111/2041-210X.12158

Andren H (1994) Effects of habitat fragmentation on birds and mammals in landscapes with different proportions of suitable habitat - a review. Oikos 71:355

Avanzi C, Del-Pozo J, Benjak A, Stevenson K, Simpson VR, Busso P, McLuckie J, Loiseau C, Lawton C, Schoening J, Shaw DJ, Piton J, Vera-Cabrera L, Velarde-Felix JS, McDermott F, Gordon SV, Cole ST, Meredith AL (2016) Red squirrels in the British Isles are infected with leprosy bacilli. Science 354(6313):744-747. https:// doi.org/10.1126/science.aah3783

Ballingall KT, McIntyre A, Lin Z, Timmerman N, Matthysen E, LurZ PWW, McInnes CJ (2016) Limited diversity associated with duplicated class II MHC-DRB genes in the red squirrel population in the United Kingdom compared with continental Europe. Conserv Genet 17:1171-1182

Barratt EM, Gurnell J, Malarky G, Deaville R, Bruford MW (1999) Genetic structure of fragmented populations of red squirrel (Sciurus vulgaris) in the UK. Mol Ecol 8:S55-S63

Belkhir K, Borsa P, Chikhi L, Raufaste N, Bonhomme F (2004) GENETIX 4.05, logiciel sous Windows TM pour la génétique des populations. Laboratoire Génome, Populations, Interactions, CNRS UMR 5000, Université de Montpellier II, Montpellier (France).

Bertolino S, Lurz PWW, Sanderson R, Rushton SP (2008) Predicting the spread of the American grey squirrel (Sciurus carolinensis) in Europe: a call for a co-ordinated European approach. Biol Conserv 141:2564-2575

Bertolino S, di Montezemolo NC, Preatoni DG, Wauters LA, Martinoli A (2014) A grey future for Europe: Sciurus carolinensis is replacing native red squirrels in Italy. Biol Invasions 16:53-62

Bosch S, Lurz PWW (2012) The Eurasian red squirrel. Die Neue Brehm-Bücherei. English Edition.

Bouzat J-L (2010) Conservation genetics of population bottlenecks: the role of chance, selection, and history. Conserv Genet 11:463-478

Carey M, Hamilton G, Poole A, Lawton C (2007) Irish squirrel survey. COFORD, Dublin

Do C, Waples RS, Peel D, Macbeth GM, Tillett BJ, Ovenden JR (2014) NeEstimator V2: re-implementation of software for the estimation of contemporary effective population size $(\mathrm{Ne})$ from genetic data. Mol Ecol Resour 14:209-214
Earl DA, vonHoldt BM (2012) STRUCTURE HARVESTER: a website and program for visualizing STRUCTURE output and implementing the Evanno method. Conserv Genet Resour 4:359-361

Evanno G, Regnaut S, Goudet J (2005) Detecting the number of clusters of individuals using the software STRUCTURE: a simulation study. Mol Ecol 14:2611-2620

Excoffier L, Lischer HEL (2010) Arlequin suite ver 3.5: A new series of programs to perform population genetics analyses under Linux and Windows. Mol Ecol Resour 10:564-567

Fahrig L (2003) Effects of habitat fragmentation on biodiversity. Annu Rev Ecol Evol S 34:487-515

Fey K, Hämäläinen S, Selonen V (2016) Roads are no barrier for dispersing red squirrels in an urban environment. Behav Ecol 27(3):741-747. https://doi.org/10.1093/beheco/arv215

Frankham R (1997) Do island population have less genetic diversity than mainland populations? Heredity 78:311-327

Frankham R (2005) Genetics and extinction. Biol Conserv 126(2):131-140

Funk WC, Lovich RE, Hohenlohe PA, Hofman CA, Morrison SA, Sillett TS, Ghalambor CK, Maldonado JE, Rick TC, Day MD, Polato NR, Fitzpatrick SW, Coonan TJ, Crooks KR, Dillon A, Garcelon DK, King JL, Boser CL, Gould N, Andelt WF (2016) Adaptive divergence despite strong genetic drift: genomic analysis of the evolutionary mechanisms causing genetic differentiation in the island fox (Urocyon littoralis). Mol Ecol 25:2176-2194. https:// doi.org/10.1111/mec.13605

Grill A, Amori G, Aloise G, Lisi I, Tosi G, Wauters LA, Randi E (2009) Molecular phylogeography of European Sciurus vulgaris: Refuge within refugia? Mol Ecol 18:2687-2699

Gurnell J, Pepper H (1993) A critical look at conserving the British red squirrel Sciurus vulgaris. Mammal Rev 23:127-137

Gurnell J, Clark MJ, Lurz PWW, Shirley MDF, Rushton SP (2002) Conserving red squirrels (Sciurus vulgaris): Mapping and forecasting habitat suitability using a geographic information systems approach. Biol Conserv 105:53

Gurnell J, Wauters LA, Lurz PWW, Tosi G (2004) Alien species and interspecific competition: Effects of introduced eastern grey squirrels on red squirrel population dynamics. J Anim Ecol 73:26-35

Hale M, Bevan R, Wolff K (2001a) New polymorphic microsatellite markers for the red squirrel (Sciurus vulgaris) and their applicability to the grey squirrel (S. carolinensis). Mol Ecol Notes 1:47-49

Hale ML, Lurz PWW, Shirley MDF, Rushton S, Fuller RM, Wolff K (2001b) Impact of landscape management on the genetic structure of red squirrel populations. Science 293:2246

Hale ML, Lurz PWW, Wolff K (2004) Patterns of genetic diversity in the red squirrel (Sciurus vulgaris L.): Footprints of biogeographic history and artificial introductions. Conserv Genet 5:167-179

Hämäläinen S, Fey K, Selonen V (2019) The effect of landscape structure on dispersal distances of the Eurasian red squirrel. Ecol Evol 9:1173-1181. https://doi.org/10.1002/ece3.4806

Hardouin EA, Baltazar-Soares M, Schilling A-K, Butler H, GarcíaRodríguez O, Crowley E, Liang W-J, Meredith A, Lurz PWW, Forster J, Kenward RE, Hodder KH (2019) Conservation of genetic uniqueness in remaining populations of red squirrels ( $\mathrm{Sci}$ urus vulgaris L.) in the South of England. Ecol Evol 9:6547-6558. https://doi.org/10.1002/ece3.5233

IWBP (2009). Isle of Wight Biodiversity Action Plan. Woodland Habitat Action Plan. 2nd review.

Jakobsson M, Rosenberg NA (2007) CLUMPP: a cluster matching and permutation program for dealing with label switching and multimodality in analysis of population structure. Bioinformatics 23:1801-1806. https://doi.org/10.1093/bioinformatics/btm233

Jombart T (2008) adegenet: an R package for the multivariate analysis of genetic markers. Bioinformatics 24:1403-1405 
Jombart T, Devillard S, Balloux F (2010) Discriminant analysis of principal components: a new method for the analysis of genetically structured populations. BMC Genet 11:94

Keenan K, McGinnity P, Cross TF, Crozier WW, Prodöhl PA (2013) diveRsity: An R package for the estimation of population genetics parameters and their associated errors. Methods Ecol Evol 4:782-788. https://doi.org/10.1111/2041-210X.12067

Kenward RE, Hodder KH (1998) Red squirrels (Sciurus vulgaris) released in conifer woodland: the effects of source habitat, predation and interactions with grey squirrels (Sciurus carolinensis). J Zool 244:23-32

Kenward RE, Holm JL (1989) What future for British red squirrels? Biol J Linn Soc 38:83-89

LaRose JP, Meredith AL, Everest DJ, Fiegna C, McInnes CJ, Shaw DJ, Milne EM (2010) Epidemiological and postmortem findings in 262 red squirrels (Sciurus vulgaris) in Scotland, 2005 to 2009. Vet Rec 167:297-302

Lloyd HG (1983) Past and present distribution of red and grey squirrels. Mammal Rev 13:69-80

Lurz PWW, Garson PJ, Wauters LA (1997) Effects of temporal and spatial variation in habitat quality on red squirrel dispersal behaviour. Anim Behav 54:427-435

McDevitt AD, Coscia I, Browett SS, Ruiz-González A, Statham MJ, Ruczyńska I, Roberts L, Stojak J, Frantz AC, Norén K, Ågren EO, Learmount J, Basto M, Fernandes C, Stuart P, Tosh DG, Sindicic M, Andreanszky T, Isomursu M, Panek M, Korolev A, Okhlopkov IM, Saveljev AP, Pokorny B, Flajšman K, Harrison SWR, Lobkov V, Ćirović D, Mullins J, Pertoldi C, Randi E, Sacks BN, Kowalczyk R, Wójcik JM (2020) Next-generation phylogeography resolves post-glacial colonization patterns in a widespread carnivore, the red fox (Vulpes vulpes), in Europe. bioRxiv. https:// doi.org/10.1101/2020.02.21.954966

Mortelliti A, Amori G, Capizzi D, Cervone C, Fagiani S, Pollini B, Boitani L (2011) Independent effects of habitat loss, habitat fragmentation and structural connectivity on the distribution of two arboreal rodents. J Appl Ecol 48:153-162

Nei M, Maruyama T, Chakraborty R (1975) The bottleneck effect and genetic variability in populations. Evolution 29:1-10

O'Meara DB, McDevitt AD, O'Neill D, Harrington AP, Turner P, Carr W, Desmond M, Lawton C, Marnell F, Rubalcava S, Sheety E, Sleeman DP, Tosh D, Waters C, O'Reilly C (2018) Retracing the history and planning the future of the red squirrel (Sciurus vulgaris) in Ireland using non-invasive genetics. Mamm Res 63:173184. https://doi.org/10.1007/s13364-018-0353-5

Ogden R, Shuttleworth C, McEwing R, Cesarini S (2005) Genetic management of the red squirrel, Sciurus vulgaris: A practical approach to regional conservation. Conserv Genet 6:511-525

Piry S, Luikart G, Cornuet JM (1999) BOTTLENECK: A computer program for detecting recent reductions in the effective population size using allele frequency data. J Hered 90(4):502-503

Pope C, Grogan R (2003) Red Squirrel Species Action Plan. HIWWT. https://www.wildonwight.co.uk/saps.php

Prentice MB, Bowman J, Khidas K, Koen EL, Row JR, Murray DL, Wilson PJ (2017) Selection and drift influence genetic differentiation of insular Canada lynx (Lynx canadensis ) on Newfoundland and Cape Breton Island. Ecol Evol 7:3281-3294. https://doi.org/ 10.1002/ece3.2945

Pritchard JK, Stephens M, Donnelly P (2000) Inference of population structure using multilocus genotype data. Genetics 155:945-959

Quine CP, Watts K (2007) Successful de-fragmentation of woodland by planting in an agriculture landscape? An assessment based on landscape indicators. J Environ Manage 90:251-259

Reed DH, Frankham R (2003) Correlation between Fitness and Genetic Diversity. Conserv Biol 17:230-237. https://doi.org/10.1046/j. 1523-1739.2003.01236.x
Rézouki C, Dozières A, Le Cœur, C, Thibault S, Pisanu B, Chapuis J-L, Baudry E (2014) A viable population of the European red squirrel in an urban park. PLoS ONE 9(8)

Rosenberg NA (2004) Distruct: a program for the graphical display of population structure. Mol Ecol Notes 4:137-138

Rushton SP, Lurz PWW, South AB, Mitchell-Jones A (1999) Modelling the distribution of red squirrels (Sciurus vulgaris) on the Isle of Wight. Anim Conserv 2:111-120

Samaras A, Youlatos D (2010) Use of forest canopy by European red squirrels Sciurus vulgaris in northern Greece: Claws and the small branch niche. Acta Theriol 55:351

Shorten M (1953) Notes on the distribution of the grey squirrel (sciurus-carolinensis) and the red squirrel (Sciurus-vulgaris-leucourus) in England and Wales from 1945 to 1952. J Anim Ecol 22:134-140

Simpson VR, Hargreaves J, Butler HM, Davison NJ, Everest DJ (2013a) Causes of mortality and pathological lesions observed post-mortem in red squirrels (Sciurus vulgaris) in Great Britain. BMC Vet Res 9:229. https://doi.org/10.1186/1746-6148-9-229

Simpson S, Blampied N, Peniche G, Dozières A, Blackett T, Coleman S, Cornish N, Groombridge JJ (2013b) Genetic structure of introduced populations: 120-year-old DNA footprint of historic introduction in an insular small mammal population. Ecol Evol 3:614-628

Statham MJ, Edwards CJ, Norén K, Soulsbury CD, Sacks BN (2018) Genetic analysis of European red foxes reveals multiple distinct peripheral populations and central continental admixture. Quat Sci Rev 197:257-266

Teacher AG, Thomas JA, Barnes I (2011) Modern and ancient red fox (Vulpes vulpes) in Europe show an unusual lack of geographical and temporal structuring, and differing responses within the carnivores to historical climatic change. BMC Evol Biol 11:214. https://doi.org/10.1186/1471-2148-11-214

Thain C, Hodder K (2015) Red squirrels in Poole Harbour. In: Shuttleworth CM, Lurz PWW, Halliwell EC (Eds) Shared experience of red squirrel conservation practice. European Squirrel Initiative. $115-121$.

Trizio I, Crestanello B, Galbusera P, Wauters LA, Tosi G, Matthysen E, Hauffe HC (2005) Geographical distance and physical barriers shape the genetic structure of Eurasian red squirrels (Sciurus vulgaris) in the Italian Alps. Mol Ecol 14:469-481

Todd R (2000) Microsatellite loci in the Eurasian red squirrel, Sciurus vulgaris L. Mol Ecol 9:2165-2166

Van Apeldoorn RC, Celada C, Nieuwenhuizen W (1994) Distribution and dynamics of the red squirrel (Sciurus-vulgaris L) in a landscape with fragmented habitat. Landsc Ecol 9:227

Verbeylen G, Wauters LA, De Bruyn L, Matthysen E (2009) Woodland fragmentation affects space use of Eurasian red squirrels. Acta Oecologica 35:94-103

Watts K, Vanhala T, Connolly T, Cottrell J (2016) Striking the right balance between site and landscape-scale conservation actions for a woodland insect within a highly fragmented landscape: A landscape genetics perspective. Biol Conserv 195:146

Wauters LA, Hutchinson Y, Parkin DT, Dhondt AA (1994) The effects of habitat fragmentation on demography and on the loss of genetic variation in the red squirrel. Proc R Soc B 255:107-111

Wauters LA, Verbeylen G, Preatoni D, Martinoli A, Matthysen E (2010) Dispersal and habitat cuing of eurasian red squirrels in fragmented habitats. Popul Ecol 52:527

Weeks AR, Sgro CM, Young AG, Frankham R, Mitchell NJ, Miller KA, Byrne M, Coates DJ, Eldridge MDB, Sunnucks P, Breed MF, James EA, Hoffman AA (2011) Assessing the benefits and risks of translocations in changing environments: a genetic perspective. Evol Appl 4:709-725

Weeks AR, Stoklosa J, Hoffmann AA (2016) Conservation of genetic uniqueness of populations may increase extinction likelihood of 
endangered species: the case of Australian mammals. Front Zool 13:31. https://doi.org/10.1186/s12983-016-0163-Z

White IC, Hughes SA (2019) Trial of a bridge for reconnecting fragmented arboreal habitat for hazel dormouse Muscardinus avellanarius at Briddlesford Nature Reserve, Isle of White, UK. Conservation Evidence 13:6-11

Wiegand P, Schröpfer R (1997) DNA fingerprinting analysis of subpopulations of the red squirrel (Sciurus vulgaris L., 1758). J Zoolog Syst Evol Res 35:71-74
Willi Y, Van Buskirk J, Hoffmann AA (2006) Limits to the Adaptive Potential of Small Populations. Annu Rev Ecol S 37:433-458

Wright S (1931) Evolution in Mendelian populations. Genetics 16:97-159

Publisher's Note Springer Nature remains neutral with regard to jurisdictional claims in published maps and institutional affiliations. 